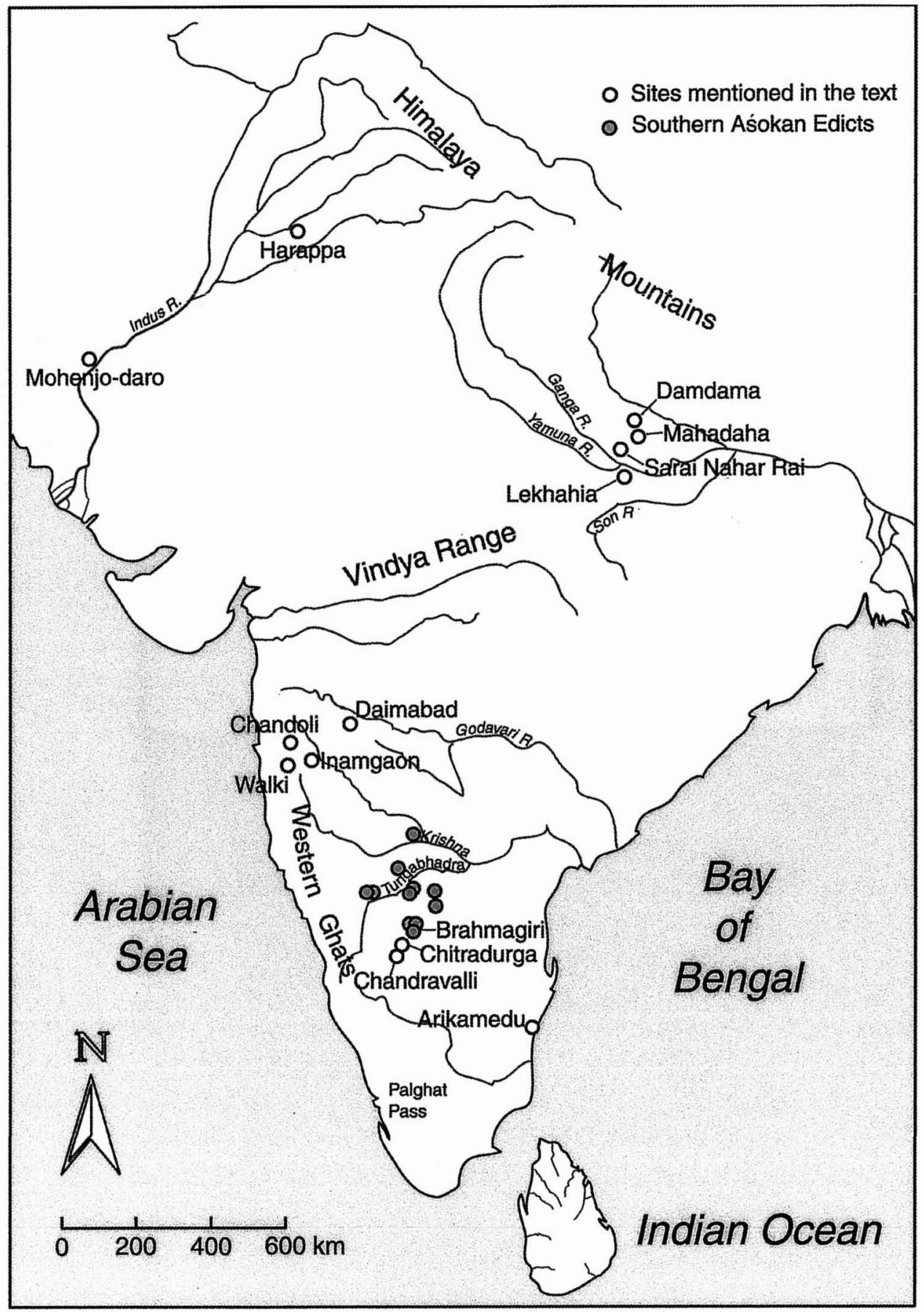

Fig. 1. Sites mentioned in the texts. 


\title{
Recasting the Foundations: New Approaches to Regional Understandings of South Asian Archaeology and the Problem of Culture History
}

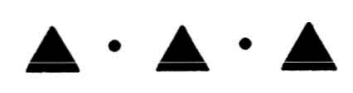

PETER G. JOHANSEN

\begin{abstract}
I have remarked elsewhere upon a tendency to devolve archaeology into a sort of dehydrated humanism, to mummify the past, to transform our predecessors into 'battle-axe folk' or 'beaker folk,' until by an instinctive and forgivable reaction, we begin almost to personify battle-axes or beakers with a sort of hungry latter-day animism.
\end{abstract}

—Sir R. E. Mortimer Wheeler (1954:229)

IN THE LAST DECADE MANY NEW AND EXCITING DEVELOPMENTS in theory and method have emerged in the research programs of South Asian archaeologists and their ongoing applications are changing both the practice and the nature of interpretation in South Asian archaeology. Until recently, the culture-history program, established in South Asian archaeology in the 1940s, has continued, without significant modification, to serve as the dominant interpretational framework. Yet, as we enter the twenty-first century, questions and approaches, both new and old, are being framed in terms that challenge the foundations of how we understand the South Asian past. Recent research engages new method and theory that has emerged largely from the discipline of anthropology, in order to transcend the confines of the culture-history approach. Many newer approaches examine sociocultural organization within regional-scale contexts, rather than focusing on static 'archaeological cultures' or isolated site-specific analyses. This volume includes eight articles that present both fresh research and data as well as innovative reworkings of pre-existing data sets and conventionally accepted readings of regional histories and prehistories.

While much new and innovative work attempting to move beyond the confines of diffusionary explanation and typological description has characterized the archaeology of South Asia in the last two decades (e.g., Misra 1974, 1996, 2001; Paddayya 1991, 1998; Pappu 2001), the epistemic foundations of culture history

Peter G. Johansen is a Ph.D. candidate in the Department of Anthropology, University of Chicago, Illinois. 
have made theoretical and methodological approaches to anthropologically oriented research questions difficult at best. Despite the discussion and critique of several scholars, namely Chakrabarti (1988), Malik (1968), and Paddayya (1990), the culture-history approach is still deeply embedded in the practice of archaeology in South Asia today.

The culture-history program essentializes the South Asian past by constructing archaeological cultures coterminous with ethnolinguistic communities, races, or 'peoples' from material-culture trait lists, and in doing so undermines the pursuit of questions and problems that explore sociological processes involved in change through time. For example, some scholars have equated the distribution of a ceramic type such as Painted Gray Ware with Painted Gray Ware 'people' or 'folk' who are considered Aryan, Indo-European speakers with a distinctive phylogenetic set of attributes (cf. Gururaja Rao 1972; Leshnik 1974; Sankalia 1962). Change through time is usually explained as the outcome of diffusionary mechanisms such as migration, invasion, or more recently as the direct result of the effects of climate and environmental change. The archaeological remains of complex and sophisticated past human processes have the regrettable circumstance of being relegated to a teleological categorical scheme that makes serious attempts at causal or consequential investigations of the dynamic past difficult.

An alternative approach to archaeological understandings of the past is to employ a more fluid notion of culture. If culture is understood as a potentially dynamic, yet meaningful order of categories, then the study of the material record of the past acquires greater analytic utility through its ability to serve as empirical evidence for the construction, maintenance, contestation, and interaction of cultural categories with a contingent and conjunctional theory of history and culture (see Sahlins 1985). Instead of seeking to establish static reified cultures through the analysis of the archaeological remains, the patterned remains of the material record are used to infer human practices and social, economic, and political processes. These processes constitute, and are constituted by, cultural categories within the contexts of unique circumstances in space and time. Essays in this volume present bold new approaches to a range of questions that problematize, reformulate and step beyond the culture-history foundations of South Asian archaeology.

RACE, LANGUAGe, ANd CUlture: PRACTiCe, Discourse, AND INDIAN CIVILIZATION

There is a strong link between colonial discourse on the character and history of Indian 'civilization' and the practice of culture history in South Asian archaeology. The origin of the culture-history modality in South Asian archaeology has deep roots in the comparative philology and ethnography of nineteenth-century colonial scholarship. Both of these disciplines were comparative, classificatory discourses, the first on language and the second on the language, physical features, habits, and customs of India's peoples. Interest in detailed political histories by early scholar-administrators soon gave way to the collection of more 'statistical' classificatory data based on the shifting needs of the East India Company's administration of an increasingly land-revenue based political economy (Dirks 2001). 
'Statistical' data in this context consisted largely of categorical trait lists of essentialized empirical observations on the physiology (seen as 'race'), language, and culture of regional populations.

The peculiar and specific nature of the data collected by colonial scholarship on the diverse peoples of South Asia and the political ends to which these data were put in no small way influenced the epistemic foundations of the emerging field of ethnology (Bayly 1999; Cohn 1996; Dirks 2001; Trautmann 1997). By the early to mid-nineteenth century, both the epistemological and ontological predispositions of philology and colonial field ethnography led, paradoxically, to an ahistorical understanding of India. Colonial scholarship viewed South Asia as the collective repository of and locus for the movement of discrete communities of peoples empirically characterized by a fixed body of linguistic and 'ethnological' (physical and cultural ${ }^{1}$ ) traits. This perspective appears to have resulted from a discursive and perhaps unconscious effort on the part of nineteenthcentury colonial scholars to address emergent tensions between universal and global modes of historiography through the study of empirical data on the language and ethnography of South Asia, collected for the purpose of colonial governance.

A common theme throughout much writing in the first half of the nineteenth century was that race and language were correlated within historical relations among peoples, particularly in South Asia. F. Max Müller's (1848) Aryan invasion hypothesis, which he established on the multiple evidentiary lines of the Vedas and contemporary distributions of language and physiology, sought to explain the current cultural condition of Indian civilization as the result of a series of invasions of a group of ethnolinguistic communities (Dravidian and Austro-Asiaticspeaking aboriginals) by those of another (Aryan Indo-European speakers). This theory of Indian civilization is perhaps one of the most perduring and insidious themes in the historiography and archaeology of South Asia, despite accumulating evidence to the contrary (cf. Chakrabarti 1988; Erdosy 1995; Leach 1990; Shaffer and Lichtenstein 1999).

By the latter half of the century, influenced by advances in the understanding of geological time scales and the release of Darwin's Origin of the Species, scholarly opinion became increasingly consolidated toward the notion that race was an ontologically natural and universal category of difference. Set within this evolutionary, biological epistemology, race could be measured and analyzed as an empirical science (Trautmann 1997:194-195). The much deeper time scale accorded to the evolution of race by contemporary geological and archaeological discoveries no longer correlated well with established time lines for the global dissemination of Indo-European languages to the Indian subcontinent (Trautmann 1997:195). Despite the divergence of philology and ethnology in the later nineteenth century, their respective positions on the diffusion and development of language and race grafted to form, what Trautmann (1997:194) has described as, the racial theory of Indian civilization. The apogee of this theoretical movement and the re-immersion of race, language, and culture into a unitary theoretical field was accomplished by the work of H. H. Risley.

As director of the Decentenial Indian Census and Ethnological Survey, Risley perhaps did more than anyone to establish a racial theory of Indian civilization. Risley (1915) argued that race was the original historical condition for caste and 
that the character of Indian civilization and society had been determined by the endogamous marriage practices of its founding 'races' that could still be observed in diluted form. Once more, within the ontological framework of race science, 'races' as genetically derived physiological categories could be determined by the quantification of measurable physical traits, such as those made of the cranium or nasal index through the emergent field of anthropometry. Race, for Risley and for much of the academy of his time, was not a socially constructed category, but rather a natural and essential feature of human evolution (see Kennedy, this volume, for a more detailed discussion of shifting paradigms of race in the context of modern palaeodemography).

Risley (1915:7-14) critiqued the notion of an affinity between language and race among the current peoples of India based on empirical grounds. But his position on the origins of Indian civilization in a country "where historical evidence can hardly be said to exist" (1915:7) gave further support to linguistically derived hypotheses of the South Asian past as one shaped by the invasion of racially discrete ethnolinguistic communities by Aryan Indo-European speakers (see also Kennedy, this volume). The study of typologically discrete categories of material culture remains from archaeological sites would only serve to reinforce the essentialist assumption that humanity could be classified according to divisions characterized by a sedimentation of race, language, and culture. This widely held position so prevalent in early anthropological thought was destroyed on empirical grounds in Americanist anthropology by the devastating yet simple critique of Franz Boas (1911) and his students. Unfortunately this critique had little effect on the practice of Old World archaeology for decades, and still falls on deaf ears in many corners of South Asian archaeology to this day.

The popular and political use of Risley's (1915) racial compendium, The Peoples of India, in terms of its ranking of peoples by castes in hierarchal order, can still be observed to this day (Inden 2000:59), demonstrating the prevalence of its authority as a modern, scientifically sanctioned text, despite having been largely discredited on theoretical and methodological grounds. Many Indian nationalist historians adopted this ontology of Indian civilization and its attendant epistemology, and the Hindu nationalist movement today remains deeply invested in its defense. The relationship between archaeology, culture-history, and the situational agendas of nationalist concerns is not restricted to South Asia, but is rather a global predicament that has afflicted the practice of archaeology throughout its history as a scholarly discipline (Kohl 1998; Trigger 1995).

\section{CULTURE-HISTORY AS SOUTH ASIAN ARCHAEOLOGICAL PARADIGM}

While the culture-history program in archaeology has its origins in the German nationalist archaeology of the late Imperial period (1900-1918) (i.e., Kossinna 1911), it was not until the publication by V. Gordon Childe in the mid 1920s of the Dawn of European Civilization (1925) and The Aryans (1926) that culturehistory began to emerge as an established and dominant paradigm in Old World archaeology (see Trigger 1989:149-173 for a brief synopsis). As noted above, the Aryan migration-invasion theory was already well established in British, European, and Indian Indological studies (e.g., F. Max Müller 1848; Risley 1915; Tilak 1916). The culture-history approach to archaeology received its first 
systematic application in South Asia in the late 1940s by V. Gordon Childe's colleague at the British academy, R.E.M. Wheeler, Director General of the Archaeological Survey of India (ASI) between 1944 and 1948.

The arrival of Wheeler in India in 1944 as Director General of the ASI has been described by Indian archaeology's most preeminent historian, D. K. Chakrabarti (1982, 1988), as marking the transition of South Asian archaeology into the modern era. Wheeler, more than any of his predecessors at the ASI, systematized and professionalized the practice of Indian archaeology by instituting a clearly defined body of techniques and methods for field and laboratory work and training. His well-known long-term agenda for the direction of fieldwork, published in 1949, laid out a detailed plan for approaching South Asian prehistory and history through a limited set of strategically planned excavations in the north and south of the subcontinent, with a special emphasis on elucidating regional chronological patterns through the exposure and analysis of stratigraphy (Wheeler 1949).

Wheeler's research focused on poorly understood periods of South Asia's past, and specifically on the pre- and protohistoric periods. His work at the sites of Arikamedu (Wheeler et al. 1946), Brahmagiri, and Chandravalli (Wheeler 1948) was seminal in the development of a chronological sequence for prehistoric and early historic South India in the era prior to radiometric dating. It is through an understanding of how Wheeler constructed and interpreted chronology from the remains of stratified archaeological deposits and the adherence to this program in subsequent years that the problem of culture history in South Asian archaeology is best approached.

Wheeler's construction of the South Indian chronology began at Arikamedu, but reached its finished form with the stratigraphic profile sections at Brahmagiri (Wheeler 1948). In brief, the sequence was constructed by examining stratigraphic concentrations of artifacts and selecting a few apparently temporally sensitive classes of material culture to represent what Wheeler referred to as archaeological cultures (see Morrison, in press). For example, the Stone Axe Culture (Neolithic) was defined by the presence of polished stone axes and a gray-pink ceramic ware, the Megalithic Culture (Iron Age) by Black-and-Red Ware ceramics and megaliths, and the Andhra Culture (Early Historic) by Russet-Coated Painted Ware. Wheeler (1948:200-202) proposed that each of these 'cultures' represented distinct peoples that successively replaced their predecessors, culminating in the invasion of the south by the Mauryan empire. Sugandhi's paper in this volume presents a critical discussion of the Mauryan presence in the south.

The construction of closed spatio-temporal 'cultural' units considered coterminous with ethnolinguistic human groups from typologically derived packages of material culture traits became by far the dominant episteme in South Asian archaeology following Wheeler's work. However, the notion of culture that is prevalent within a culture history of South Asia's archaeological past is a descriptive rather than explanatory category. The "culture" in culture history consists of the artifacts themselves, which are viewed as the reflection of a people's normative customs, beliefs, and behavior. It is decidedly disinvested of any sense of diverse systems of meaning, agency, socio-political difference, or any form of internal variability, nor does it appreciate the dynamic and processual nature of human behavior through time. As closed-off spatio-temporal, analytic entities, archaeological cul- 
tures essentialize past peoples into units of identity that have little character beyond a description of the artifacts they produced. In the context of this discussion, the irony of Wheeler's remarks that open this paper is especially poignant.

Cultural change within this system is theoretically predisposed to diffusionary mechanisms of explanation, and in situ development is stifled by a mode of thinking which views humankind as inherently conservative and uninventive (Morrison 1994:89). As such, cultural change comes in punctuated episodes of one people either diffusing their ideas to another or effacing them completely through a limited repertoire of processes such as invasion, migration, or interaction. The circularity of this sort of analytic exercise alone should be justification for its serious reconsideration.

Wheeler's diffusionary mechanism for punctuated cultural change (or replacement) was in keeping with earlier and contemporary ethnological and historiographical theories of Indian civilization, most notably the Aryan invasion hypothesis. In fact, Wheeler's (1947:81-83) report from his excavations at the site of Harappa used archaeological data to situate the demise of the Indus civilization within a narrative of South Asian history that had virile Aryan, Indo-European invaders triumph over a less martial, non-Aryan Indian civilization. His explanation of the prehistoric chronology of South India used the same diffusionary mechanism, invasion, to explain temporal changes in material culture categories as indicative of the replacement of one people by another. While the business of establishing a sound chronological framework is an essential first step towards understanding of the archaeology of any region, this exercise does not inherently entail the construction of culture history and its categorical epistemology.

Given the monumental critique of the culture history program in British and Americanist archaeology (e.g., Binford 1963, 1965; Clarke 1968), its primacy in South Asian research has a curious history. Wheeler's influence on the future of South Asian archaeology was considerable, and his training of a generation of young South Asian archaeologists in the theory and method of culture history established this theoretical mode as something of a scholarly tradition, but this alone cannot account for its continued popularity, even in the face of empirical critique and alternative approaches. The tenets of the culture history approach and the diffusionary mode of explanation were deeply entrenched in historical discourse on South Asia's past. The position of H. D. Sankalia, the widely proclaimed 'doyen of Indian archaeology,' on the subject of "the New Archaeology" and its utility for Indian archaeology in the 1970s, is somewhat telling in this regard.

H. D. Sankalia's approach to archaeological method and theory was, in practice, culture history at its most transparent. While it is true that Sankalia (1962) and Subbarao (1958) were responsible for bringing geographical and environmental considerations to South Asian archaeology, the basic tenets of the culturehistory program remained unchanged in their work. For Sankalia the unity of race, language, and culture was an important quality of archaeological 'cultures,' the very definition of which consisted of limited constellations of material culture traits. Although Sankalia $(1962: 274)$ considered the possibility of indigenous in situ origins for certain elements of India's 'civilizational' character, his preference was clearly for a diffusionary model in which the unequal development of South Asia was explained by the supposition that, "the bearers of superior cul- 
tures" migrated or invaded the subcontinent through geographic corridors, settling the arable river valleys and displacing indigenous hunter-gatherers to highland regions. Sankalia (1977:45-46,84-86) largely rejected the need for Indian archaeology to adopt more meaningful explanatory frameworks and advances in method and theory that were then being advocated by the "new archaeology." He considered the theoretical and methodological state of Indian archaeology to be amply equipped to approach the proper limits of explanation in archaeological analysis (i.e., culture history vs. anthropology).

A number of critiques have important bearing on this discussion of the problematic nature of the culture-history program in South Asian archaeology (e.g., Chakrabarti 1988; Malik 1968; Paddaya 1990). Malik's (1968) critique of the current state of South Asian archaeology-dismissed by Sankalia (1977:77) as largely irrelevant-argued that the culture-history program, as applied to the archaeology of India, lacked both explanatory theory and an adequate understanding of culture. Malik pointed to the descriptive nature of culture history, arguing for a more structural-functionalist approach to the archaeological record, through which South Asian archaeology might develop into a more anthropologically oriented discourse. He characterized the limited explanatory potential of South Asian culture-history theory as both evolutionary, in terms of its progressivist account of archaeological cultures, and diffusionist, in terms of its singular mode for the explanation of change. He also disputed the very simple and normative understanding of the concept of culture employed by archaeologists to construct culture-history sequences and the arbitrary fashion with which this was accomplished (Malik 1968:46-47). While the details of Malik's program for theoretical reform in South Asian archaeology are in places unclear and certainly dated, his rejection of the culture-history approach as methodologically unsound, theoretically descriptive, and overly deterministic mark this work as a seminal piece in the critique of culture history in South Asian archaeology.

A more empirically driven critical assessment of the culture-history program in South Asia is Chakrabarti's (1988) critique of diffussionism as explanatory framework. Chakrabarti (1988:20-28), using the results of decades of excavation and research, demonstrated the untenable position of several well-established diffusionary positions on the West Asian origins of the Indian Palaeolithic, food production during the Neolithic, metallurgy in the Chalcolithic period and Iron Age, and the rise of the Indus civilization. He argued that in each case the analysis of stratigraphy demonstrated time and again a marked continuity in regional archaeological sequences with very little evidence for the diffusion of technology, food production, or sociopolitical organization. To explain the continued use of diffusionary explanatory frameworks Chakrabarti (1988:32) pointed to the popularity in South Asian scholarship of a race/language/culture theory of South Asian civilization. He attributes this position to a national pride associated with an understanding of contemporary South Asian culture as a synthesis of a diverse racial and linguistic heritage, especially an Aryan Indo-European ethnicity with origins beyond the subcontinent.

Paddayya (1990:46) argues for a "paradigm coexistence" in which culture history serves as a natural first step in the understanding and analysis of a region's prehistory, after which the use of processual or ideational theoretical frameworks can be engaged to approach questions such as those dealing with social, political, 
and economic processes and systems of meaning. Determining the chronology of a site or region through the stratigraphic assessment of material culture and the construction of typologies does not entail, by necessity, the construction of archaeological cultures or any of the ontological and epistemic assumptions of the culture-history approach. Maintaining the epistemological link between chronology and archaeological culture building embeds a normative view of culture into archaeological interpretations of the past. Despite Paddayya's position regarding the utility of culture history within the context of coexisting theoretical paradigms, his work has been exemplary in forging new directions in archaeological research.

Despite the persistence of culture-history in South Asian archaeology, the last two and a half decades have seen a proliferation of new questions and approaches toward the understanding and interpretation of the subcontinent's unique past. One of the most important loci for new and innovative research is Deccan College in Pune, India. Many of H. D. Sankalia's former students and junior colleagues have made significant contributions to regional issues in prehistory which step beyond the theoretical parameters of the culture-history approach, engaging theoretical frameworks such as cultural ecology and structural-functionalism. The work of Paddayya $(1985,1991,1998)$ on the Paleolithic period in the Hungsi Valley and Neolithic ashmounds and settlements in northern Karnataka, for example, demonstrates how the incorporation and development of new theoretical and methodological perspectives were applied to approach the elucidation of regional social and economic processes through the archaeological record. Dhavalikar's (1988; Dhavalikar et al. 1988) extensive work on the Deccan Chalcolithic and in particular the site of Inamgaon, and V. N. Misra's $(1996,2001)$ work on the Mesolithic period in central India are two more examples of innovative research programs based at Deccan College.

In addition to the independent research programs of South Asian scholars, many innovative regionally based multidisciplinary investigations of South Asian archaeology have been undertaken in collaboration with scholars from universities beyond the subcontinent during the last two decades. Among these are Possehl's (Possehl and Raval 1989) work on the Indus civilization in the Saurashtran region and Chalcolithic period Rajasthan, the Harappa Archaeological Research Project (Meadow 1991; see papers by Clark and Meyer, this volume) and the FrenchPakistani excavations in Baluchistan (Jarrige et al. 1995). Other important projects are the Vijayanagara Metropolitan Survey (Morrison 1995; Sinopoli and Morrison 2001) and the British-Sri Lankan excavations at Anuradhapura (Coningham 1999). These projects have also made significant contributions to theoretical and methodological issues in South Asian archaeology.

It is from within this context of collaborative, multidisciplinary research that the papers in this volume emerge. Authors in this volume have left behind the normative view of culture present in culture-history accounts of the archaeological record in pursuit of research problems dealing with regional social, political, and economic organization of South Asia's past through engagement with a wide variety of method and theory from a diversity of disciplinary origins (see Fig. 1). They have also moved beyond the conservatism of structural-functionalism and the determinism of cultural ecology. The results are new questions and research, which seek to understand the material record of South Asia's diverse past as part of 
complex, contingent, sociological processes. The future of South Asian archaeology, as a discipline dedicated to elucidating a richly diverse past, requires the application of theory and method sophisticated enough to infer from the material record the unique and dynamic nature of past cultural contexts. This entails multidisciplinary research exploring multiple perspectives and lines of evidence with critical, self-reflexive concern for understanding the plurality and difference of the dynamic dialectic of structure and agency involved with past human societies.

\section{PLAN OF THE VOLUME}

A common problem orientation of the authors speaking in this volume is a concern with how archaeologists deploy method and theory in understanding past systems of regional organization. Their responses are largely made manifest through a move back to epistemic basics, which beg the questions how and why we know what we think we know about the South Asian past. Within the body of papers in this volume, two thematic approaches are presented. The first employs archaeological data to re-examine conventionally held interpretations of regional social, political, and economic organization in South Asian history and prehistory, as opposed to restricting spatial analyses to examinations of the distribution of sites and 'archaeological cultures' or excavation contexts restricted to stratum. A variety of perspectives, utilizing theory and method from the expansive corpus of work on spatial analysis, and the critical analysis of epigraphy and text are presented here in order to address questions that challenge the epistemic foundations of previously held perspectives of regional spatial organization. The second approach offers new interpretations of regional patterning of particular categories of material culture by questioning and reformulating the theoretical underpinnings of contemporary, conventionally held understandings of specific bodies of archaeological data. Perspectives and methodological approaches include biocultural anthropology, gender theory, and the critical evaluation and construction of typology through the deployment of ethnoarchaeological studies.

Papers by Abraham and Sugandhi challenge understandings of ancient Indian political geographies located in current South Asian historical discourse. Abraham questions the validity of textual claims for the existence of the expansive and hegemonic kingdoms of the Sangam era through the examination of a corpus of archaeological data which casts doubt on the extent of these claims. Theorizing the relationship between material culture and the construction and maintenance of social identities, she argues for a multivariate approach to the archaeological record, in which multiple classes of artifacts are analyzed at multiple scales to explore the dynamic boundaries of past social identities. In her empirical critique of the political landscape of Early Historic Tamilakam, she argues that shifting the scale of archaeological analyses to examine the social and economic activities of smaller, local contexts rather than focusing on broad claims of elite political control found in textual sources may prove to be a more effective strategy in understanding social and ethnic identities given the rather homogeneous character of the archaeological database.

Sugandhi, in her reexamination of the Aśokan edicts of the south Deccan region, confronts, through a theoretical approach concerned with imperial strategies, the long-held maxim of contemporary Indian history that the geographic 
extent of a massive pan-Indian Mauryan empire was delineated by the distribution of its third emperor's famous stone edicts. Shifting the terms of analysis from the study of empire as territorial entity to imperialism as political process, she approaches questions of intended meaning and audience in these Aśokan edicts through multiple disciplinary perspectives. By examining their archaeological context, historical content, and linguistic composition, Sugandhi explores patterns of location and visibility together with issues of address and comprehension in the south Deccan edicts, demonstrating the utility and importance of exploring multiple disciplinary perspectives to approach questions of political process through the archaeological record.

Lewis and Patil's paper examines the political and economic character of the eighteenth-century Chitradurga Nayaka polity through an analysis of regional spatial patterns of its archaeological landscape. Employing a combined analysis of their own archaeological reconnaissance survey and an examination of East India Company cartography, they have created a GIS database through which they have reconstructed both regional settlement patterns and detailed site plans. Lewis and Patil use theory from locational geography to approach enduring temporal trends in site location and hierarchy assessing the role of political and economic factors involved with these patterns through time.

The paper by Raczek juxtaposes marked changes in subsistence practices at the site of Inamgaon with continuities in regional burial practices at this Chalcolithic site in the west Deccan region of India. Employing structuration and practice theory to examine this conjuncture, she also explores issues of identity, personhood, and meaning from the patterned remains of these burials, pushing her analysis beyond the issue of status recognition. Another paper concerned with issues of identity in the archaeological record is Clark's analysis of terracotta figurines from the site of Harappa. Employing an epistemic framework informed by current developments in feminist theory, Clark critically examines representations of the body in the terracotta figurines from Harappa in which sex, gender, and sexuality are fluid components in the expression of a uniquely Indus subjectivity of sexual and social difference.

Meyer's paper explores another form of material remains from the site of Harappa, hearth features. Employing observations from his own ethnoarchaeological research in the region surrounding the site of Harappa as a heuristic guide, Meyer builds a functional typology for archaeological hearths based on elements of morphology and content. Typology here is used as an instrument toward the analysis of social and economic practices such as cooking and resource procurement and will undoubtedly lead to enhanced understandings of broader processes involved with subsistence and cuisine at Harappa.

Lukacs and Pal present a bioarchaeological approach to the human skeletal remains from three Mesolithic sites in the Ganga Valley. Their analyses of skeletal variability (musculoskeletal stress, osteoarthritis, stature, limb length and proportion) are used to infer habitual activities and biological adaptations associated with a hunter-gatherer lifeway in a tropical environment. The final paper in the volume by K.A.R. Kennedy, explores how changing questions and concerns in the field of biological anthropology have dramatically changed over the last 40 years. Drawing from his extensive knowledge and first-hand involvement in palaeoanthropology, Kennedy details many of the shifting trends in theory and 
research in biological anthropology in South Asia, demonstrating the importance of human skeletal remains in the continued pursuit of anthropologically derived questions of South Asian palaeodemography.

Each in their own way, the authors in this volume are concerned with engaging a wide corpus of method and theory to better understand the rich and textured material record of South Asia's past. Understanding culture as a fluid, diverse, and dynamic category has moved their research beyond the analytic limitations of the culture-history approach, recasting both the epistemic possibilities and the interpretational and explanatory potential of the archaeological record. As archaeological research that challenges conventional normative understandings of South Asia's past and seeks to explore multiple dimensions and vocalities in the archaeological record, the articles in this volume provide new directions and perspectives from which we hope further productive work will emerge.

\section{ACKNOWLEDGMENTS}

The papers presented in this volume were originally given at the $66^{\text {th }}$ Annual Meetings of the Society for American Archaeology in New Orleans, Louisiana (2001), in a session entitled "Rethinking South Asian Archaeology: New Research and Perspectives." I would like to thank all of the participants in this symposium for their contributions. Comments on the introduction from Kathleen Morrison, Sandra Morrison, Adam Smith, Miriam Stark, and Namita Sugandhi were very helpful and deeply appreciated. All responsibility for errors and opinions are my own.

\section{NOTES}

1. By cultural I am here referring to a notion of culture temporally designated by George Stocking (1974:19) as prevalent in anthropology and ethnology prior to 1950 in which culture is viewed "in terms of inventories of material artifacts and concrete behavioural manifestations ...," i.e., customs and habits.

\section{REFERENCES CITED}

BAYLY, S.

1999 Caste, Society and Politics in India from the Eighteenth Century to the Modern Age. Cambridge: Cambridge University Press.

BOAS, F.

1911 Handbook of American Indian Languages, Part I. Bulletin No. 40. Washington: Bureau of American Ethnology.

BINFORD, L.

1963 Archaeology as anthropology. American Antiquity 28:217-225.

1965 Archaeological systematics and the study of culture process. American Antiquity $31: 203-210$.

Chakrabarti, D. P.

1982 The development of archaeology in the Indian sub-continent. World Archaeology $13: 326-343$.

1988 Theoretical Issues in Indian Archaeology. New Delhi: Munshiram Manoharlal.

Childe, V. G.

1925 The Daun of European Civilization. London: Kegan Paul.

1926 The Aryans: A Study of Indo-European Origins. New York: Alfred A. Knopf.

Clarke, D. L.

1968 Analytical Archacology'. London: Methuen. 
Cohn, B. S.

1996 Colonialism and its Forms of Knowledge: The British in India. Princeton: Princeton University Press.

Coningham, R.

1999 Anuradhapura: The British-Sri Lankan Excavations at Arundhapura Salgaha Watta 2, vol. 1. Oxford: Archeopress.

Dhavalikar, M. K.

1988 The First Farmers of the Deccan. Pune: Ravish.

Dhavalikar, M. K., H. D. Sankalia, and Z. D. Ansari

1988 Excavations at Inamgaon, vol. 1, pt. i-ii. Pune: Deccan College Postgraduate and Research Institute.

DiRKS, N.

2001 Castes of Mind: Colonialism and the Making of Modern India. Princeton: Princeton University Press.

ERdosy, G.

1995 Language, material culture and ethnicity: Theoretical perspectives, in The Indo-Aryans of Ancient South Asia: Language, Material Culture and Ethnicity: 1-31, ed. G. Erdosy. Berlin: Walter de Gruyer.

Gururaja Rao, B. K.

1972 Megalithic Culture in South India. Prasanga: University of Mysore.

INDEN, R.

2000 Imagining India. Bloomington and Indianapolis: Indiana University Press.

Jarrige, C., J.-F. Jarrige, R. Meadow, and G. Quivron

1995 Mehrgarh: Field Reports 1974-1985, from Neolithic times to the Indus Civilization. Karachi: Department of Culture and Tourism of Sindh, Pakistan.

KонL, P.

1998 Nationalism and archaeology: On the constructions of nations and the reconstructions of the remote past. Annual Review of Anthropology $27: 223-246$.

Kossinna, G.

1911 Die Herkunft der Germain. Leipzig: Kabitzsch.

LEACH, E.

1990 Aryan invasions over four millennia, in Culture Through Time Anthropological Approaches: 227-245, ed. E. Ohnuki-Tierney. Stanford, CA: Stanford University Press.

LESHNIK, L.

1974 South Indian 'Megalithic' Burials: The Pandukal Complex. Wiesbaden: Franz Steiner Verlag.

MALIK, S. C.

1968 Indian Civilization: The Formative Period. Delhi: Motilal, Banarsidass.

Max Müller, F.

1848 On the relation of the Bengali to the Arian and aboriginal languages of India, in Three Linguistic Dissertation Read at the Meeting of the British Association in Oxford: 319-350. From the Report of the British Association for the Advancement of Science for 1847. London: Richard and John E. Taylor.

MEADOW, R.

1991 Harappan Excavations 1986-1990: A Multidisciplinary Approach to Third Millennium Urbanism. Madison, WI: Prehistory Press.

Misra, V. N.

1974 Ecological adaptations during the terminal Stone Age in western and central India, in Ecological Backgrounds of South Asian Prehistory: 28-51, ed. K.A.R. Kennedy and G. Possehl. Ithaca: South Asia Program, Cornell University.

1996 Mesolithic India: History and current status of research, in The Prehistory of Asia and Oceania, vol. 16:321-328, ed. G. Afanas'ev, S. Cleuziou, J. R. Lukacs, and M. Tosi. Forlì: ABACO Edizioni.

2001 The Mesolithic age in India, in Indian Archaeology in Retrospect, vol. 1, PrehistoryArchacology of South Asia: 111-126, ed. S. Settar and R. Korisettar. Delhi: Manohar.

MORRISON, K.

1994 States of theory and states of Asia: Regional perspectives on states in Asia. Asian Perspectives 33(2): 183-196. 
1995 Fields of Victory: Vijayanagara and the Course of Intensification. Berkeley: University of California.

in press Brahmagiri revisited: A re-analysis of the South Indian sequence, in South Asian Archaeology 2001, ed. C. Jarrige and V. LeFevre. Editions Recherche sur les Civilisations. Paris: ADPF.

PADDAYYA, K.

1982 The Acheulian Culture of the Hunsgi Valley (Peninsular India): A Settlement System. Poona: Deccan College Postgraduate and Research Institute.

1990 The New, Archaeology and Aftermath: A Vicw from Outside the Anglo-American World. Pune: Ravish Publishers.

1991 The ashmounds of South India: Fresh evidence and possible explanation. Bulletin of the Deccan College Post-Graduate Research Institute 51-52:573-626.

1998 Evidence of Neolithic cattle-penning at Budihal, Gulbarga District, Karnataka. South Asian Studies 14:141-153.

Pappu, S

2001 A Re-examination of the Palaeolithic Archaeological Record of Tamil Nadu, South India. Oxford: Archaeopress.

Possehl, G., AND M. H. Raval

1989 Harappan Civilization and Rojdi. Delhi: Oxford and IBH and the American Institute of Indian Studies.

Risley, H.

1915 [1908] The People of India. Delhi: Oriental Book Reprint Corporation.

SAHLINS, M.

1985 Islands of History. Chicago: University of Chicago Press.

Sankalia, H. D.

1962 Prehistory and Protohistory of India and Pakistan. Bombay: Bombay University Press.

1977 New Archaeology: its Scope and Application to India: D. N. Majumdar Lectures. Lucknow, India: Ethnographic and Folk Culture Society.

Shaffer, J. G., And D. A. Lichtenstein

1999 Migration, philology and South Asian archaeology, in Aryan and Non-Aryan in South Asia: Evidence, Interpretation and Ideology: 239-260, ed. J. Bronkhorst and M. M. Deshpande. Cambridge, MA: Harvard Oriental Series.

SinOpoli, C., AND K. Morrison

2001 The greater metropolitan region, in New Light on Hampi, ed. J. Fritz and G. Michell. Marg 53(1): 100-111.

Stocking, G. W., JR.

1974 Introduction: The basic assumptions of Boasian anthropology, in A Franz Boaz Reader: The Shaping of American Anthropology, 1883-1911: 1-21, ed. G. W. Stocking Jr. Chicago: University of Chicago Press.

SubBaraO, B.

1958 The Personality of India. Baroda: Faculty of Arts, Maharaja Sayajirao University of Baroda.

TILAK, B. G.

1916 Orion or Researches into the Antiquity of the Vedas. Poona: Ashtekar and Co.

Trautmann, T. R.

1997 Aryans and British India. Berkeley: University of California Press.

Trigger, B.

1989 A History of Archacological Thought. Cambridge: Cambridge University Press.

1995 Romanticism, nationalism, and archaeology, in Nationalism, Politics and the Practice of Archacology: 263-279, ed. P. Kohl and C. Fawcett. Cambridge: Cambridge University Press.

WHEELER, R.E.M.

1947 Harappa 1946: The defenses and Cemetery R 37. Ancient India 3:58-130.

1948 Brahmagiri and Chandravalli 1947: Megalithic and other Cuctures in Mysore State. Ancient India 4:181-231.

1949 Archaeological fieldwork in India: Planning ahead. Ancient India 5:4-11.

1954 Archacology from the Earth. London: Penguin. 
Wheeler, R.E.M., A. Ghosh, and K. Deva

1946 Arikamedu: An Indo-Roman trading-station on the East Coast of India. Ancient India $2: 17-124$.

\section{ABSTRACT}

The archaeological record of South Asia's rich and diverse past has been largely dominated by interpretational frameworks, which have the construction of culture histories as their core, if not their end. Normative and conservative understandings of culture implicit in the culture-history paradigm have resulted in the construction of static archaeological cultures coterminous with ethnolinguistic communities, races or 'peoples' from material culture trait lists. An understanding of culture that recognizes its contingent, dynamic, and categorical nature is required in order to approach the complex and unique sets of historical circumstances and relationships that have shaped South Asia's past. Articles in this volume present new research and perspectives that pose a variety of new questions about the organization of social, political, and economic processes that push beyond the epistemic limitations of the culture-history foundations of South Asian archaeology. Keywords: South Asia, archaeology, race, language, culture, culture history, diffusion. 